\title{
Akuntabilitas Pengelolaan Alokasi Dana Desa Di Desa Watesumpak Kecamatan Trowulan Kabupaten Mojokerto
}

\author{
Lilik Pujiati \\ STIE PGRI Dewanatara Jombang
}

Korespondensi: lilik.dewantara@gmail.com

\begin{abstract}
abstrak
Penelitian ini dilakukan untuk mengetahui bagaimana akuntabilitas pengelolaan Alokasi Dana Desa Watesumpak Kecamatan Trowulan Mojokerto dan Apakah Desa ini sudah melaksanakan pengelolaan administrasi keuangan yang sesuai dengan peraturan. Sebagai informan terpilihnya adalah Perangkat Desa, Tim Pelaksana Desa serta masyarakat yang dianggap dapat mewakili unit penelitian dalam pengelolaan Alokasi Dana Desa. Penelitian dilakukan dengan wawancara secara mendalam dan dengan cara pengamatan langsung pada pelaksanaan Alokasi Dana Desa. Hasil penelitian ini menunjukkan bahwa Pengelolaan Alokasi Dana Desa Watesumpak Kecamatan Trowulan Mojokerto sudah akuntabel mulai dari perencanaan, pelaksanaan, penatausahaan, pelaporan, dan pertanggungjawaban. Namun ada satu kegiatan yang kurang sesuai yaitu kegiatan belanja barang dan jasa. Desa Watesumpak Kecamatan Mojokerto sudah melaksanakan pengelolaan administrasi keuangan yang sesuai dengan peraturan Bupati Mojokerto Nomor 7Tahun 2015. Hal ini tidak terlepas dari kerjasama mulai kepala desa, perangkat desa, BPD dan semua elemen di Desa Watesumpak.
\end{abstract}

Kata kunci : Alokasi Dana Desa, Transparansi, akuntabilitas

abstract

This research was conducted to find out how the accountability of Funds Allocation Management in Watesumpak Village, Trowulan Mojokerto Subdistrict and whether this Village has implemented financial administration management in accordance with the regulations. As the chosen informant is the Village Tool, the Village Implementation Team and the community who are considered to be able to represent the research unit in the management of the Village Fund Allocation. The research was conducted by in-depth interviews and direct observation on the implementation of Village Fund Allocation. The results of this study indicate that the Management of Fund Allocation of Watesumpak Village in Trowulan District, Mojokerto has been accountable starting from planning, implementing, administering, reporting, and accountability. But there is one activity that is not appropriate, namely the activities of goods and services. Watesumpak Village, Mojokerto Subdistrict has carried out financial administration management in accordance with Mojokerto Regent's Regulation Number 7 Year 2015. This cannot be separated from the collaboration starting from the village head, village apparatus, BPD and all elements in the Watesumpak Village.

Keywords: Village Fund Allocation, Transparency, Accountability

\section{A. PENDAHULUAN}

Transisi politik yang terjadi di Indonesia menghasilkan dua proses politik yang berjalan secara simultan, yaitu desentralisasi dan demokratisasi. Kedua proses politik itu terlihat jelas dalam pergeseran format pengaturan politik di area lokal maupun nasional, yaitu dari pengaturan politik yang bersifat otoritarian-sentralistik menjadi lebih demokratisdesentralistik. Jadi Akuntabilitas publik merupakan elemen terpenting dan merupakan tantangan utama yang dihadapi pemerintah dan pegawai negeri. (Muslimin dkk, 2012:80)

Desa sebagai pilar utama pembangunan di Indonesia, telah mendapat perhatian yang sangat serius dari pemerintah. Berbagai program pemerintah yang berpihak kepada desa telah diwujudkan antara lain dengan pemberian bantuan dari pemerintah dengan nilai 
ratusan juta, yang dimaksudkan untuk mempercepat pembangunan di desa. Pemerintah juga memberikan bantuan lain berupa pelatihan dan pendampingan dalam pengelolaan dana yang telah diberikan tersebut (Mutiarni, R., Utomo, L. P., \& Zuhroh, S. 2017), agar tepat sasaran dan akuntabel. Akuntabilitas pengelolaan keuangan desa adalah satu hal yang wajib untuk diupayakan karena hanya dengan pengelolaan keuangan desa yang akuntabel visi dari UU Desa akan tercapai. Di dalam proses pembahasan pasal 72 di DPR, terlihat jelas bagaimana para pemangku kepentingan mengkhawatirkan keuangan desa tidak dikelola dengan baik yang dapat berujung dengan proses hukum bagi pengelolanya yaitu kepala desa dan perangkat desa dan sekaligus akan menjadikan visi UU Desa menjadi tidak tercapai.

Mardiasmo dalam faridah (2015:2) menyatakan, secara teoritis desentralisasi diharapkan akan menghasilkan dua manfaat nyata, yaitu: pertama mendorong peningkatan partisipasi, prakarsa dan kreatifitas masyarakat dalam pembangunan, serta mendorong pemerataan hasil-hasil pembangunan (keadilan) di seluruh daerah dengan memanfaatkan sumberdaya dan potensi yang tersedia di masyarakat- masyarakat daerah; kedua: memperbaiki alokasi sumberdaya produktif melalui pergeseran peran pengambilan keputusan publik ke tingkat pemerintahan yang paling rendah yang memiliki informasi yang paling lengkap, sedangkan tingkat pemerintahan yang paling rendah adalah desa. Oleh karena itu otonomi desa benar-benar merupakan kebutuhan yang harus diwujudkan.

Implementasi otonomi bagi desa akan menjadi kekuatan bagi pemerintah desa untuk mengurus, mengatur dan menyelenggarakan rumah tangganya sendiri, sekaligus bertambah pula beban tanggung jawab dan kewajiban desa, namun demikian penyelenggaraan pemerintahan tersebut tetap harus dipertanggungjawabkan. Pertanggungjawaban yang dimaksud diantaranya adalah pertanggungjawaban dalam pengelolaan anggaran desa. Untuk saat ini kendala umum yang dirasakan oleh sebagian besar desa terkait keterbatasan dalam keuangan desa. Seringkali Anggaran Pendapatan dan Belanja Desa (APBDes) tidak berimbang, antara penerimaan dengan pengeluaran.

Sistem pengelolaan dana desa yang dikelola oleh pemerintah desa termasuk didalamnya mekanisme penghimpunan dan pertanggungjawaban merujuk pada Undangundang Nomor 33 Tahun 2004 tentang Perimbangan Keuangan antara Pemerintah Pusat dan Pemerintah Daerah. Dalam aturan tersebut dijelaskan bahwa pendanaan pembangunan yang dilakukan oleh pemerintah daerah termasuk didalamnya pemerintah desa menganut prinsip money follows function yang berarti bahwa pendanaan mengikuti fungsi pemerintahan yang menjadi kewajiban dan tanggung jawab masing-masing tingkat pemerintahan. Dengan kondisi tersebut maka transfer dana menjadi penting untuk menjaga/menjamin tercapainya standar pelayanan publik minimum. Konsekuensi dari pernyataan tersebut adalah desentralisasi kewenangan harus disertai dengan desentralisasi fiskal. Realisasi pelaksanaan desentralisasi fiskal di daerah mengakibatkan adanya dana perimbangan keuangan antara kabupaten dan desa yang lebih dikenal sebutan Alokasi Dana Desa (ADD). Dalam sistem pemerintahan yang ada saat ini, desa mempunyai peran yang strategis dalam membantu pemerintah daerah dalam proses penyelenggaraan pemerintahan, termasuk pembangunan. Semua itu dilakukan sebagai langkah nyata pemerintah daerah mendukung pelaksanaan otonomi daerah di wilayahnya.

Salah satu pemerintah daerah yang melaksanakan otonomi daerah adalah kabupaten Mojokerto yang di dalamnya terdapat kecamatan Trowulan. Kecamatan Trowulan merupakan salah satu daerah otonom yang ada di Jawa Timur yang telah melaksanakan prinsip-prinsip otonomi daerah dengan berusaha mengoptimalkan potensi desa demi terselenggaranya pemerintahan yang bersih. Wujud nyata Kecamatan Trowulan dalam 
membantu dan meningkatkan partisipasi pemerintah desa adalah dengan terus berupaya meningkatkan alokasi dana kepada desa yang dapat dipergunakan untuk mendukung penyelenggaraan kewenangan dan urusan rumah tangganya. Dalam pelaksanaan program Alokasi Dana Desa, belum semua desa dapat berjalan seperti yang diharapkan. Pemerintah Desa masih berperan besar dalam pelaksanaan program, sedangkan masyarakat belum tentu terlibat secara optimal. Kondisi ini juga mungkin terjadi di Desa Watesumpak Kecamatan Trowulan Kabupaten Mojokerto. Atas dasar hal tersebut peniliti tertarik untuk mengetahui bagaimana akuntabilitas dalam pelaksanaan program Alokasi Dana Desa di Desa Watesumpak Kecamatan Trowulan Kabupaten Mojokerto.

\section{B. KAJIAN PUSTAKA}

\section{Pengelolaan Keuangan Desa}

Menurut Permendagri Nomor 113 tahun 2014, pengelolaan keuangan desa adalah keseluruhan kegiatan yang melipui perencanaan, pelaksanaan, penatausahaan, pelaporan dan pertanggungjawaban keuangan desa. Keuangan desa adalah semua hak dan kewajiban desa yang dapat dinilai dengan uang serta segala sesuatu berupa uang dan barang yang berhubungan dengan pelaksanaan hak dan kewajiban desa.

\section{Asas - Asas Pengelolaan Keuangan Desa}

Di dalam pengelolaan keuangan desa terdapat asas umum keuangan desa dan asas pengelolaan keuangan desa. Asas umum keuangan desa sebagaimana yang diatur di dalam Bab VI Keuangan dan Kekayaan Desa, Bagian Kesatu Keuangan Desa, Paragraf 1 Umum, Pasal 90 sampai dengan pasal 94 Peraturan Pemerintah Nomor 43 Tahun 2014 tentang Peraturan Pelaksanaan Undang-Undang Nomor 6 tahun 2014 tentang Desa. Sedangkan asas-asas pengelolaan keuangan desa sebagaimana yang diatur di dalam Bab II Asas Pengelolaan Keuangan Desa, Pasal 2 Peraturan Menteri Dalam Negeri Nomor 113 Tahun 2014 tentang Pengelolaan Keuangan Desa.

Adapun asas umum keuangan desa sebagaimana yang diatur di dalam Peraturan Pemerintah Nomor 43 Tahun 2014 tentang Peraturan Pelaksanaan Undang-Undang Nomor 6 tahun 2014 tentang Desa, yaitu:

1. Penyelenggaraan kewenangan Desa berdasarkan hak asal usul dan kewenangan lokal berskala Desa didanai oleh APB Desa

2. Penyelenggaraan kewenangan lokal berskala Desa selain didanai oleh APB Desa, juga dapat didanai oleh anggaran pendapatan dan belanja negara dan anggaran pendapatan dan belanja daerah.

3. Penyelenggaraan kewenangan Desa yang ditugaskan oleh Pemerintah didanai oleh anggaran pendapatan dan belanja Negara

4. Dana anggaran pendapatan dan belanja negara dialokasikan pada bagian anggaran kementerian/lembaga dan disalurkan melalui satuan kerja perangkat daerah kabupaten/kota;

5. Penyelenggaraan kewenangan Desa yang ditugaskan oleh pemerintah daerah didanai oleh anggaran pendapatan dan belanja daerah

6. Seluruh pendapatan Desa diterima dan disalurkan melalui rekening kas Desa dan penggunaannya ditetapkan dalam APB Desa

7. Pencairan dana dalam rekening kas Desa ditandatangani oleh kepala Desa dan bendahara Desa

8. Pengelolaan keuangan Desa meliputi: (a). perencanaan; (b). pelaksanaan; (c). penatausahaan; (d). pelaporan; dan (e). pertanggungjawaban.

9. Kepala Desa adalah pemegang kekuasaan pengelolaan keuangan Desa

JAD: Jurnal Riset Akuntansi dan Keuangan Dewantara

Vol 1 No 1, April 2018

http://ejournal.stiedewantara.ac.id/index.php/JAD/issue/view 
10. Dalam melaksanakan kekuasaan pengelolaan keuangan Desa, kepala Desa menguasakan sebagian kekuasaannya kepada perangkat Desa.

11. Pengelolaan keuangan Desa dilaksanakan dalam masa 1 (satu) tahun anggaran terhitung mulai tanggal 1 Januari sampai dengan 31 Desember.

Sedangkan, asas-asas pengelolaan keuangan desa sebagaimana yang diatur dalam Peraturan Menteri Dalam Negeri Nomor 113 Tahun 2014 tentang Pengelolaan Keuangan Desa, yaitu: 1) Asas transparan, yaitu prinsip keterbukaan yang memungkinkan masyarakat untuk mengetahui dan mendapatkan akses informasi seluas-Iuasnya tentang pengelolaan keuangan desa. 2) Asas akuntabel, yaitu prinsip setiap kegiatan dan hasil akhir kegiatan harus dapat dipertanggungjawabkan kepada masyarakat desa sesuai dengan ketentuan peraturan perundang-undangan. 3) Asas partisipatif, yaitu prinsip yang mengikutsertakan kelembagaan desa dan unsur masyarakat desa dalam tata kelola keuangan desa. 4) Asas tertib dan disiplin anggaran, yaitu prinsip bahwa keuangan desa dikelola secara tepat waktu dan tepat guna yang didukung dengan bukti-bukti administrasi yang dapat dipertanggungjawabkan.

Penelitian ini juga mengambil asas akuntabilitas pengelolaan Alokasi Dana Desa sesuai dengan Permendagri nomor 113 tahun 2014 mengenai asas akuntabel yaitu prinsip setiap kegiatan dan hasil akhir kegiatan harus dapat dipertanggungjawabkan kepada masyarakat desa sesuai dengan ketentuan peraturan perundang-undangan.

\section{Kerangka Konseptual}

Sebagaimana hal yang diatur di dalam pasal 93 ayat (1) Peraturan Pemerintah Nomor 43 Tahun 2014 tentang Peraturan Pelaksanaan Undang- Undang Nomor 6 tahun 2014 tentang Desa sebagaimana diubah dengan Peraturan Pemerintah Nomor 47 Tahun 2015, pengelolaan keuangan desa meliputi: perencanaan, pelaksanaan, penatausahaan, pelaporan dan pertanggungjawaban. Rerangka pemikiran akuntabilitas Alokasi Dana Desa (ADD) di Desa Watesumpak Kecamatan Trowulan Kabupaten Mojokerto tahun 2015 dapat dijelaskan sebagai berikut:

1. Dasar utama pengelolaan Alokasi Dana Desa (ADD) yang dilakukan desa adalah Undang-Undang Nomor 6 Tahun 2014 tentang Desa. Dalam pasa72 ayat 1 disebutkan bahwa salah satu pendapat desa adalah alokasi dana Desa yang merupakan bagian dari dana perimbangan yang diterima Kabupaten/kota. Sedangkan pada ayat (4) disebutkan Alokasi dana Desa sebagaimana dimaksud pada ayat (1) huruf d paling sedikit $10 \%$ (sepuluh perseratus) dari dana perimbangan yang diterima Kabupaten/Kota dalam Anggaran Pendapatan dan Belanja Daerah setelah dikirangi Dana Alokasi Khusus.

2. Dalam melaksanakan ketentuan pasal 72 tersebut, telah diterjemahkan dalam Peraturan Pemerintah Nomor 43 Tahun 2015 tentang Peraturan Pelaksanaan Undang-Undang Nomor 6 Tahun 2014 tentang Desa. Dalam pasal 96 ayat (1) disebutkan Pemerintah daerah Kabupaten/Kota mengalokasikan dalam angggran pendapatan dan belanja daerah Kabuoaten/Kota ADD setiap tahun anggaran. Sedangakan pada ayat (2) ADD sebagaimana dimaksud pada ayat (1) paling sedikit 10\% (sepuluh perseratus) dari dana perimbangan yang diterima Kabupaten/Kota dalam anggaran pendapatan dan belanja daerah setelah dikurangi Dana Alokasi Khusus.

3. Sebagai acuan pengelolaan ADD bagi desa diterbitkan Peraturan Menteri Dalam Negeri Republik Indonesia Nomor 113 Tahun 2014 tentang Pengelolaan Keuangan Desa. Dalam pasal 2 Peraturan Menteri tersebut dinyatakan Keuangan desa dikelola bedasarkan asas-asas transparan,akuntabel,partisipatif serta dilakukan dengan tertib dan disiplin anggaran. Sedangakan pada pasal 3 disebutkan bahwa Kepala Desa adalah 
pemegang kekuasaan pengelolaan keuangan desa dan mewakili Pemerintah Desa dalam kepemilikan kekayaan milik desa yang dipisahkan. Berdasaraka hal tersebut maka pengelolaan ADD sebagai salah satu sumber pendapatan desa, maka Kepala Desa sebagai penanggung jawab keuangan di desa harus menerapkan prinsip pengelolaan keuangan desa seperti halnya pada peraturan Menteri tersebut.

4. Pada tingkat Kabupaten, Peraturan Bupati Mojokerto Nomor 7 Tahun 2015 menjadi patokan desa dalam pengelolaan keuangan khususnya ADD tahun 2015. Pada Peraturan Bupati tersebut disebutkan bahwa pada ayat (1) Pengelolaan keuangan ADD merupakan bagian yang tidak terpisahkan dari pengelolaan keuangan Desa yang dituangkan dalam peraturan Desa tentang APBDesa; sedangkan pada ayat (2) Pengelolaan keuangan sebagaimana dimaksud pada ayat (1) harus direncanakan, dilaksanakan, diawasi dan dievaluasi secara terbuka dengan melibatkan seluruh unsur masyarakat di Desa, serta pada ayat (3) pengelolaan keuangan sebagaimana dimaksud ayat (2) harus menggunakan prinsip transparan, adil, efisien, efektif akuntabel, terukur dan terkendali serta dilaksanakan sesuai dengan ketentuan Peraturan PerundangUndangan yang berlaku.

5. Sebagai pengelolala keuangan ADD, Kepala Desa Watesumpak harus memperhatikan prinsip-prinsip pengelolaan keuangan desa, sebagaimana yang telah diatur dengan peraturan diatasnya. Untuk melakukan pengelolaan keuangan desa,, Kepala Desa harus menerbitkan Peraturan Desa tentang Anggaran Pendapatan dan Belanja Desa maupun Peraturan Desa tentang Pertanggung jawaban Anggaran Pendapatan dan Belanja Desa. Pertanggung Jawaban tersebut harus disampaikan kepada Badan Permusyawaratan Desa (BPD) Yang terbentuk dalam laporan keterangan Penyelenggaraan Pemerintahan Desa (LKPPD).

\section{METODE PENELITIAN}

Sesuai dengan masalah yang akan dibahas oleh peneliti, jenis penelitian ini menggunakan penelitian deskriptif kualitatif, Analisis data dalam penelitian deskriptif kualitatif dilakukan bersamaan dengan proses pengumpulan data sampai memperoleh suatu kesimpulan, sehingga analisis data tersebut dapat mencapai tujuan yang diinginkan. Dalam penelitian ini peneliti menggunakan model interaktif dalam analisis data. Miles dan Huberman (Sugiyono, 2011;334) mengemukakan bahwa Aktifitas dalam analisis data kualitatif dilakukan secara interaktif dan berlangsung secara terus menerus sampai tuntas, sehingga datanya sudah jenuh. Aktifitas dalam analisis data yaitu reduksi data, penyajian data, pengumpulan data, dan penarikan kesimpulan

Penjelasan dalam komponen-komponen analisis data, sebagai berikut :

1. Pengumpulan data. Pengumpulan data merupakan kegiatan yang dilakukan selama data yang diperlukan belum cukup, jika telah cukup dalam pengambilan kesimpulan maka pengumpulan data dapat dihentikan. Langkah dalam pengumpulan data adalah : wawancara, observasi dan dokumentasi.

2. Reduksi data. Setelah melakukan pengumpulan data maka selanjutnya yang dilakukan adalah proses pemilihan, penyederhanaan, mengarahkan, dan membuang yang tidak perlu data kasar yang muncul dari catatan-catatan lapangan. Proses reduksi berlangsung terus sampai laporan akhir penelitian disusun. Reduksi merupakan bagian analisis yang mempertegas, memperpendek, membuat fokus, membuang hal-hal yang tidak penting sehingga peneliti dapat menarik kesimpulan dengan mudah.

3. Penyajian Data. Proses selanjutnya setelah adanya proses pemilihan, penyederhanaan, mengarahkan, dan membuang yang tidak perlu adalah penyajian hasil data. Penyajian 
data yang dilakukan dalam penelitian ini adalah mengorganisasikan informasi secara sistematis, menggabungkan dan mengaitkan antar data, menggambarkan proses dan fenomena yang ada dari objek penelitiaan.

4. Penarikan kesimpulan. Proses terakhir yang dilakukan pada penelitian ini adalah menarik kesimpulan. Kesimpulan dapat berupa kegiatan yang berupa pengembangan penelitian dalam satuan data. Penarikan kesimpulan dalam penelitian ini dihubungkan dengan pihak yang relevan.

Dengan demikian teknik analisis yang harus dilakukan, dalam penelitian ini sebagai berikut :1) Mengidentifikasi kebijakan pengelolaan dana Alokasi Dana Desa di Desa Watesumpak tahun 2016 dan 2017. 2) Mentabulasi jawaban responden. 3) Menilai Akuntabilitas. 4) Mendeskripsikan tingkat akuntabilitas Alokasi Dana Desa tahun 2016 dan 2017. 5) Penarikan kesimpulan.

\section{HASIL PENELITIAN}

Secara geografis letak Desa Watesumpak sangat strategis karena berbatasan dengan kawasan industri dan juga batas pemerintahan Kecamatan. Dan Topografi ketinggian desa ini adalah berupa daratan sedang yaitu sekitar $151 \mathrm{~m}$ di atas permukaan air laut dan curah hujan di Desa Watesumpak rata-rata mencapai $100 \mathrm{~mm}$. Curah hujan terbanyak terjadi pada bulan Desember - maret . Akuntabilitas Perencanaan ADD di Desa Watesumpak dapat diketahui dari prosentase perencanaan penggunaan ADD Desa Watesumpak pada tahun anggaran 2016 dan tahun anggaran 2107 tahap 1. Besaran prosentase perencanaan tersebut sudah sesuai dengan ketentuan hukum yang berlaku atau belum. Dalam mengambil kesimpulan akuntabilitas perencanaan, peneliti menganalisa berdasarkan pada data perencanaan penggunaan ADD di Desa Watesumpak. Hasil analisis dokumen tersebut dapat diuraiakan sebagai berikut:

1. Pemerintah Desa Watesumpak dalam merencankan penggunaan ADD telah memlaui musyawarah Desa untuk membahas rencana penggunaan ADD. Musyawarah tersebut dihadiri oleh unsur pemerintah Desa, BPD, LKD, dan tokoh masyarakat serta Tim Dari Kecamatan. Rancangan penggunaan ADD yang disepakati dituangkan dalam rencana penggunaan ADD.

2. Untuk penghasilan tetap dan tunjangan perangkat desa Watesumpak sebesar Rp. 252.466.200,00 atau sebesar 60 persen dari dana ADD yang diterima oleh desa Watesumpak. Pada tahun 2017 tahap 1 tidak ada yang berubah dengan apa yang telah ada pada tahun anggaran 2016. Dari dana tersebut digunakan untuk penghasilan tetap kepala desa dan perangkat desa sebesar Rp. 252.466.200 Sedangkan banyaknya kepala desa dan perangkat desa yang mendapat penghasilan tetap sebanyak 12 orang. Pada pasal 81 Peraturan Pemerintah Republik Indonesia Nomor 43 Tahun 2014 disebutkan bahwa Pengalokasian ADD untuk penghasilan tetap kepala desa dan perangkat desa adalah maksimal sebesar $60 \%$ dari ADD. ADD yang diperoleh desa Watseumpak adalah 420.777.000. Apabila dihubungkan dengan aturan tersebut, maka peruntukan penghasilan tetap kepala desa dan perangkat desa tidak menyalahi aturan tersebut.

3. Belanja operasional Pemerintah Desa yaitu operasional pemerintah desa sebesar Rp. 38.493.240 atau sebesar 9,15\%, operasional BPD sebesar Rp. 12.000.000 atau sebesar 2,85\% dari dana ADD serta operasional RT/RW sebesar Rp. 5.500.000 atau sebesar $1,31 \%$ dari ADD yang diperoleh. Jumlah operasional pemerintah desa secara keseluruhan dengan sumber dana dari ADD di Desa Watseumpak sebesar Rp 50.493.240 atau sebesar $12 \%$ dari ADD yang ada. Dalam peraturan Bupati Mojokerto nomor 7 
Tahun 2015 disebutkan bahwa belanja operasional pemerintah desa sebesar 30\%. Merujuk berdasarkan ketentuan tersebut, maka penggunakan ADD untuk kegiatan operasional pememrintah desa Watesumpak tahun anggaran 2016 sudah sesuai dengan aturan atau dengan kata lain sudah akuntabel.

4. Sejalan dengan hal tersebut untuk penggunaan ADD dalam pemabangunan kanotr desa juga sudah sesuai dengan peraturan Bupati. Dalam peraturan Bupati Mojokerto nomor 7 tahun 2015 bahwa ADD digunakan untuk pembangunan sarana dan prasarana infrastruktur desa termasuk di dalamnya sarana prasarana pemerintahan desa yaitu pembangunan kantor atau balai desa.

5. Pengawasan pada tahap perencanaan dilakukan oleh LPM dan BPD pada saat rapat tentang APBdesa di Desa Watesumpak dan juga selama proses penentuan Alokasi Dana Desa.

Dari analisis yang telah diuraikan di atas, maka dapat disimpulkan bahwa perencanaan penggunaan ADD di desa Watesumpak telah sesuai dengan peraturan yang berlaku. Dalam hal ini dasar pengalokasian ADD tersebut adalah peraturan Menteri Dalam Negeri nomor 113 tahun 2014 tentang Keuangan Desa dan peraturan Bupati Mojokerto nomor 7 tahun 2015 tentang pedoman pengelolaan ADD tahun 2016 dan 2017. Dengan demikian akuntabilitas perencanaan ADD di desa Watesumpak kecamatan Troewulan pada tahun 2016 dan 2017 Tahap 1 sudah akuntabel.

Akuntabilitas pelaksanaan ADD di Desa Watesumpak dilihat dari laporan pelaksanaan kegiatan ADD. Kegiatan yang telah dilakukan apakah sesuai dengan RAB yang telah direncanakan atau belum sesuai. Disamping itu dalam melakukan kegiatan ADD apakah pemrintah desa melibatkan masyarakat desa utamanya dalam tenaga kerja dan tim pelaksana kegiatan (TPK) sebagai pelakasanaannya atau semua kegaitan dimonopoli kepala desa saja.

Berdasarkan hasil wawancara dengan informan peneliti melakukan analisis dan hasilnya adalah sebagai berikut:

1. Secara keseluruhan pelaksanaan ADD di desa wateumpak sudah sesuai dengan RAB yang telah disusun sebelumnya. Artinya besaran pelaksanaan ADD sudah sesuai denagan besaran RAB yang disusun sebelumnya.

2. Pelaksana kegiatan ADD yang sudah ditunjuk kepala Desa sudah bekerja dan melaksanakan sesuai dengan peraturan yang ditentukan. TPK melaksanakan kegiatan sesuai dengan RAB. Kepala desa tidak memonopoli kegaitan ADD, namun tetap menjadi pengawas setiap kegiatan yang telah dilaksanakan TPK. Melalui laporan yang telah disampaikan TPK dan pengecekan lapangan.

3. Namun ada satu kegiatan yang kurang sesuai yaitu kegiatan belanja barang dan jasa. Setelah dikonfirmasi dengan TPK dalam hal ini Bendahara Desa memang terjadi ketidaksesuaian. Ketidaksesuaian tersebut terjadi pada rekening jasa kantor. Dalam rekening jasa kantor terdapat rekening listrik, administrasi bank, pajak bunga bank dan rekening internet yang besarnya setiap bulan tidak sama. Sedangkan dalam perencanaan atau RAB digunakan nilai besar sehingga terjadi selisih atau antara RAB dan pelaksanaannya.

4. Pengawasan pada tahap pelaksanaan ADD dilakukan oleh BPD secara kelembagaan. Hal ini sesuai dengan peraturan bupati Mojokerto nomor 7 tahun 2015.

Berdasarkan analisis yang disampaikan tersebut maka dapat disimpulkan bahwa pelaksanaan ADD di desa Watesumpak untuk tahun anggaran 2016 sudah akuntabel. Semua kegiatan yang didanai ADD sudah dilaksanakan oleh TPK dan sesuai dengan RAB yang disusun sebelumnya. Besaran kegiatan yang bersumber dari ADD 
yang dilaksanakan sesuai dengan perencanaan yang telah dilakukan pemerintah desa Watesumpak. Akuntabilitas besaran yang diperoleh sudah sesuai artinya besaran dana pada perencaaan sama dengan pelaksanaan. Kalau terjadi ketidaksesuaian tersebut disebabkan kegiatan yang dibiayai tidak dapat direncanakan atau diprediksi dengan tepat, yaitu pada rekwening listrik atau telepon.

Untuk akuntabilitas penatausahaan ADD di Desa Watesumpak dilihat dari Bendahara desa wajib melakukan pencatatan setiap penerimaan dan pengeluaran kegiatan ADD, melakukan tutup buku setiap akhir bulan dan membuat buku kas umum, buku pembantu pajak, dan buku bank. Kegiatan yang telah dilakukan apakah sesuai dengan peraturan atau belum sesuai. Disamping itu dalam melakukan penatausahaan kegiatan ADD apakah pemerintah desa melibatkan masyarakat desa utamanya catatan penerimaan dan pengeluaran dana ADD Desa Watesumpak.

Berdasarkan wawancara dengan responden, peneliti melakukan analisis dengan hasil analisis dapat diuraikan sebagai berikut: 1) Secara keseluruhan penatausahaan ADD di desa watesumpak sudah disusun sebelumnya. Artinya pencatatan setiap penerimaan dan pengeluaran dana dari ADD desa Watesumpak sudah dilakukan. 2) Bendahara desa sudah melakukan tutup buku setiap akhir bulan. TPK melaksanakan kegiatan sesuai dengan RAB yang kemudian pelaporan semuanya diberitahukan kepada bendahara desa. Kepala desa tidak memonopoli penatausahaan kegiatan ADD, namun tetap menjadi pengawas setiap catatan buku setiap bulan. 3) Bendahara desa sudah membuat buku kas umum, buku pembantu pajak, dan buku bank. Buku khusus desa yang selalu dibuat oleh pemerintah desa ini untuk membantu dalam pelaporan khususnya dengan pihak lain yang di luar pemerintah desa agar tidak terjadi kesalahan prosedur.

Berdasarkan analisis yang disampaikan tersebut maka dapat disimpulkan bahwa penatausahaan ADD di desa Watesumpak untuk tahun anggaran 2016 dan 2017 sudah akuntabel. Bendahara desa di desa Watesumpak kecamatan Trowulan sudah melakukan pencatatan setiap penerimaan dan pengeluaran kegiatan ADD, melakukan tutup buku setiap akhir bulan dan membuat buku kas umum, buku pembantu pajak, dan buku bank.

Akuntabilitas pelaporan ADD di Desa Watesumpak dilihat dari Tim Pelaksana Kegiatan ADD menyusun dan melaporkan laporan Akhir pelaksanaan ADD serta kepala desa melaporkan SPJ Realisasi kegiatan ADD ke pemerintah kabupaten melalui pemerintahan kecamatan dan kepada Badan Pemusyawaratan Desa (BPD). Kegiatan pelaporan yang telah dilakukan apakah sesuai dengan peraturan atau belum sesuai. Disamping itu dalam melakukan pelaporan kegiatan ADD apakah pemerintah desa melibatkan masyarakat desa utamanya pelaporan kepada BPD di Desa Watesumpak.

Berdasarkan wawancara dengan responden, peneliti melakukan analisis dengan hasil analisis dapat diuraikan sebagai berikut:

1. Secara keseluruhan pelaporan ADD di desa watesumpak sudah dibuat sebelumnya secara periodik yakni semesteran dan tahunan. Artinya pemerintah desa Watesumpak menyusun dan melaporkan laporan Akhir pelaksanaan ADD dengan baik.

2. Kepala Desa melaporkan SPJ Realisasi kegiatan ADD ke pemerintah kabupaten. Kepala desa tidak hanya melakukan pelaporan kegiatan ADD secara individu, namun tetap bekerjasama dan dibantu oleh bendahara desa, Tim Pelaksana Kegiatan ADD dan perangkat desa lainnya.

3. Kepala Desa melaporkan SPJ Realisasi kegiatan ADD kepada Badan Pemusyawaratan Desa (BPD) di desa Watesumpak secara periodik. Pelaporan ini sebagai bentuk 
pertanggungjawaban terhadap pelaksanaan ADD pada anggaran tahun 2016 dan anggaran tahun 2017 tahap 1.

Berdasarkan analisis yang disampaikan tersebut maka dapat disimpulkan bahwa pelaporan ADD di desa Watesumpak untuk tahun anggaran 2016 dan 2017 sudah akuntabel. Pemerintah Desa menyusun dan melaporkan laporan Akhir pelaksanaan ADD serta kepala desa melaporkan SPJ Realisasi kegiatan ADD ke pemerintah kabupaten melalui pemerintahan kecamatan dan kepada Badan Pemusyawaratan Desa (BPD).

Untuk akuntabilitas penggunaan Alokasi Dana Desa di desa Watesumpak di lihat dari bukti pertanggungjawaban baik berupa bukti Surat Pertanggungjawaban Laporan Realisasi Anggaran (SPJ LRA) maupun laporan lainnya. Adapun hasil analisis dapat diuraikan sebagai berikut:

1. Berdasarkan Laporan Realisasi Anggaran (LRA) yang disusun oleh Desa Watesumpak diperoleh informasi bahwa secara keseluruhan kegiatan ADD di desa Watesumpak telah selesai 99\%. Semua kegiatan ADD telah dipertanggungjawabkan $100 \%$ terkecuali kegiatan pada belanja barang dan jasa tercapai 99\%. Hal ini karena belanja barang dan jasa terdapat jasa kantor yang secara keseluruhan tidak bisa terserap.

2. Berdasarkan observasi Surat Pertanggungjawaban yang telah disusun oleh desa Watesumpak diperoleh data bahwa secara keseluruhan telah disusun SPJ baik SPJ penghasilan tetap, perbedayaan masysarakat maupun SPJ pembangunan.

3. Dapat diketahui Tim Pelaksana Kegiatan sudah memahami dan mengerti tenang tata kelola administrasi keuangan ADD karena selalu terdapat petunjuk dan arahan dari kepala desa, Tim ADD Kecamatan Trowulan maupun dari Tim ADD Pemerintah Kabupaten Mojokerto.

\section{E. PENUTUP}

Dari hasil penelitian tetntang akuntabilitas Pengelolaan Alokasi Dana Desa di Desa Watesumpak Kecamatan Trowulan Kabupaten Mojokerto, dapat diambil beberapa kesimpulan sebagai berikut:

1. Pengelolaan Alokasi Dana Desa Watesumpak Kecamatan Trowulan Mojokerto sudah akuntabel mulai dari perencanaan, pelaksanaan, penatausahaan, pelaporan, dan pertanggungjawaban. Namun ada satu kegiatan yang kurang sesuai yaitu kegiatan belanja barang dan jasa karena belanja barang dan jasa terdapat jasa kantor yang secara keseluruhan tidak bisa terserap.

2. Desa Watesumpak Kecamatan Mojokerto sudah melaksanakan pengelolaan administrasi keuangan yang sesuai dengan peraturan Bupati Mojokerto Nomor 7 Tahun 2015. Hal ini tidak terlepas dari kerjasama mulai kepala desa, perangkat desa, BPD dan semua elemen di Desa Watesumpak.

Dari beberapa penjelasan dan kesimpulan di atas, maka untuk pencapaian sasaran maksimal dalam pembangunan partisipatif masyarakat desa yang diimplementasikan melalui program Alokasi Dana Desa (ADD), maka harus ada pembenahan dalam beberapa hal sebagai berikut:

1. Untuk meningkatkan keberhasilan program Alokasi Dana Desa (ADD) di Desa Watesumpak Kecamatan Trowulan perlu dilakukan langkah-langkah sebagai berikut: a) Pelatihan bagi Perangkat Desa selaku Tim Pelaksana Desa tentang manajemen dan administrasi pengelolaan ADD, b) Penyediaan sarana yang lebih memadai bagi Tim Pelaksana Kegiatan ADD untuk menunjang kegiatan supervisi, pemantauan, evaluasi dan monitoring kegiatan ADD di desa, c) Dilakukan monitoring dan evaluasi secara 
berkelanjutan untuk memperbaiki kinerja di semua sisi baik fisik, teknis, maupun administrasi (pertanggungjawaban/SPJ).

2. Pembinaan pengelola ADD merupakan sarana efektif untuk keberhasilan program ADD. Oleh karena itu pemahaman prinsip partisipatif, transparansi, dan akuntabilitas harus dilakukan seefektif kepada aparat pemerintah desa, BPD, lembaga kemasyarakatan desa, tokoh masyarakat dan tokoh agama guna meningkatkan semangat, motivasi, dan kreatifitas masyarakat dalam pembangunan desa.

3. Perlu dibangun kembali kepercayaan masyarakat terhadap pemerintah dengan jalan melaksanakan prinsip responsif terhadap kebutuhan atau usulan masyarakat dan merealisasikannya dalam bentuk kegiatan pembangunan lain di desa.

\section{DAFTAR PUSTAKA}

Lembaga Administrasi Negara dan Badan Pengawasan Keuangan dan Pembangunan RI 2000, Akuntabilitas dan Good Governance, Modul 1-5, Modul Sosialisasi Sistem Akuntabilitas Kinerja Instansi Pemerintah (AKIP), LAN BPKP RI, Jakarta.

Mardiasmo. 2002. Otonomi Daerah dan Manajemen Keuangan Daerah. Yogyakarta. . 2009. Akuntansi Sektor Publik. Yogyakarta

Mutiarni, R., Utomo, L. P., \& Zuhroh, S. (2017). Pendampingan Pencatatan Transaksi Keuangan Pada Koperasi Bunga Harapan Desa Ceweng. Comvice: Journal Of Community Service, 1(1), 33-38.Muslimin, Mappamiring, St. Nurmaeta. 2012. Akuntabilitas Pengelolaan Alokasi Dana Desa di Desa Punagaya Kecamatan Bangkala Kabupaten Jeneponto. Makassar: Universitas Muhammadiyah Makassar.

Peraturan Bupati Mojokerto Nomor 7 Tahun 2015 tentang Pedoman Pelaksanaan

Alokasi Dana Desa Kabupaten Mojokerto Tahun 2016. Peraturan Pemerintah Nomor 47 Tahun 2014 tentang Desa.

Peraturan Pemerintah Nomor 43 Tahun 2014 tentang Petunjuk Pelaksanaan UndangUndang Desa

Peraturan Pemerintah Nomor 60 Tahun 2014 tentang Dana Desa

Permendagri Nomor 113 tahun 2014 tentang Pengelolaan Keuangan Desa

Sugiyono. 2012. Memahami Penelitian Kualitatif. Bandung: Alfabeta.

Undang-undang Nomor 33 Tahun 2004 tentang Perimbangan Keuangan antara Pemerintah Pusat dan Pemerintah Daerah 